\title{
Do E-government Services 'Really' Make Life Easier? Analyzing Demographic Indicators of Turkish Citizens' E-government Perception Using Ordered Response Models
}

\author{
Ali Kemal Çelik \\ Atatürk University, Department of Quantitative Methods \\ Email: akemal.celik@atauni.edu.tr \\ Ahmet Kamil Kabakuş \\ Atatürk University, Department of Quantitative Methods
}

\author{
Doi:10.5901/mjss.2015.v6n1p185
}

\section{Abstract}

\begin{abstract}
The evolution stages of e-government services should be well-established for more effective e-government services and more satisfied citizens. This study aims to determine factors affecting e-government services with an emphasis on demographic attributes in a developing country. Particularly, the study investigates the effectiveness of past e-government services in terms of their contribution to human life. For these purposes, the data obtained from 2011 Life Satisfaction Survey were analyzed using four distinctive ordered response models including ordered logit, generalized ordered logit, heterogeneous choice model and partial constrained generalized ordered logit models due to the natural ordering of the dependent variable. The results of this study show that there are significant relationships among the factors that influence perception of e-government, namely, current residence, educational level, and occupational sector for all models, additionally household size for heterogeneous choice model. Consequently, partial constrained generalized logit model was found to have more parsimonious than other models. This study was probably the first attempt to analyze e-government service quality using four different ordered response models in e-government research literature. The outcome of this study may provide valuable information and enable benchmarking options for future e-government policies.
\end{abstract}

Keywords: e-government services; generalized ordered logit; heterogeneous choice model, partial constrained generalized ordered logit

\section{Introduction}

In the contemporary era, information technology undertakes crucial strategic roles on transforming governance which is considered as one of the key elements for the strategies in the government modernization (Tseng et al., 2008; Grand \& Chau, 2005). The diffusion of personal computers in the 1980s enabled the public administrators with a personal information technology system opening a new period of information technology use in government (Yildiz, 2007). In fact, for better government services, both information technology and information systems behave as a catalyst in the overwhelmingly shift towards the emerging e-government form (Tseng et al., 2008; Ho, 2002). Along with the successful deployment of e-government and given the central role of the Internet in current e-government trends, government modernization has been experiencing an ongoing evolution process from early interinstitutional efforts based on partnerships between government and private sector (Aldrich et al., 2002) to much more modernized one-stop government services with an instant access. Since e-government is adopted as an evolutionary phenomenon, Layne and Lee (2001) proposed a four-stage model for the development of e-government including cataloguing, transaction, vertical, and horizontal integration for a fully functional e-government service. Particularly, vertical and horizontal integration stages clearly define the important relations between e-government service providers and citizens. DeBenedictis et al. (2002) have also divided e-government services into four categories and government-to-citizen services take their respectable place as an important e-government delivery agency. In terms of e-government evolution, two important dynamics should be addressed. First dynamic underlines the importance of the Internet on transactional and integrated applications of e-government services and their evolvement. Secondly, state and local governments have followed the evolution of national governments on technological and organizational adoption (Gil-Garcia \& Martinez-Moyano, 2007). In essence, these stages should be understood and implemented carefully for more effective e-government services and more satisfied citizens.

As a developing country, e-government is also an essential element of Turkey's efforts for reorganizing its 
administrative system and establishing a national information and communication system infrastructure (Kaya Bensghir \& Yildiz, 2002). Turkey was connected to the Internet in 1993 and the number of Internet users in the country has reached to almost 38 million people, ranking the country to be one of the top five countries in Europe (Internet World Stats, 2013). The official e-government website of Turkey came into service on December, 2008 which provides an infrastructure whereby citizens can have secure access to the information and services and a joint structure is being established for development, provision, and improvement of e-government services by identifying the needs of the citizens and government agencies (TURKSAT, 2009; Naralan et al., 2013). As of October, 30 2014, the Turkish e-government gateway has more than 19 million registered users and provides 1,026 services of 141 public institutions (The National Egovernment Official Website of Turkey, 2014). However, in order to improve quality of e-government services, citizens' responses on the success of e-government adoption should be monitored periodically. In that way, potential issues regarding the access of these services may be instantly overcomed and possible breakdowns on every stages of egovernment development proposed by Layne and Lee (2001) may be successfully prevented. This paper aims to evaluate the usefulness of e-government services on citizens' daily life in a developing country. For this purpose, factors affecting the Turkish citizens' e-government perception would be a valuable information for the future implementation of e-government services. The dependent variable of this study has a natural hierarchical ordering with discrete outcomes, so the use of ordered response models will be convenient. The present paper intends to determine some of these potential indicators using four distinctive econometric models that may also satisfy benchmarking purposes. The rest of the paper proceeds as follows. Section 2 reviews the current e-government literature concerning the determination of potential factors affecting e-government services. Section 3 gives information about the research methodology and the sample of the study. Section 4 introduces the estimation results and their interpreation in detail with respect to the fitted models. Section 5 discusses the estimation results, limitations of the present work and make recommendations and suggestions for both future research and policy making.

\section{Literature Review}

There is a rapidly growing literature that determines possible factors affecting e-government use, adoption, and perception. Many earlier studies have mentioned the relationship between perception of e-government services and demographic factors. The contribution of age differences on e-government perception has been extensively highlighted (Choudrie \& Dwivedi, 2005; Hamner \& Al-Qahtani, 2009; Gauld et al., 2010). However, a recent work (Aladwani, 2013) found no significant relationship between respondents' age and their e-government use. Some past studies (Jaeger, 2003; Akman et al., 2005; Li et al., 2005; Hamner \& Al-Qahtani, 2009; Gauld et al., 2010; Aladwani, 2013; Naralan et al., 2013; Venkatesh et al., 2014) found that intention to use e-government services increases with higher education levels. Not surprisingly, gender was a significant contributing factor of e-government perception in the literature. Some earlier studies found that males (Akman et al., 2005; Liu et al., 2014; Venkatesh et al., 2014) were more likely to have positive perception about e-government services, in contrast with other research findings (Aladwani, 2013) whereas female citizens showed greater tendency to use these services. On the other hand, other studies (Li et al., 2005; Gauld et al., 2010) found no relationship between e-government use or support and respondents' gender. Some past research (Liu et al., 2014) indicated that current residence was an important indicator of positive e-government perception, while another recent studies (Rey \& Ozymy, 2011; Venkatesh et al., 2014) found that income level was a predictor of e-government adoption.

Along with demographic characteristics, past applied research on e-government use or perception also addresses personal characterictics. A very great number of studies found that perceived ease of use (Hung et al., 2006; AlAwadhi \& Morris, 2009; Lean et al., 2009; Alomari et al., 2010; Verdegem \& Verdeye, 2009; Susanto \& Goodwin, 2010; Rufín et al., 2012; Venkatesh et al., 2012; Hung et al., 2013; Mostafa \& El-Masry, 2013; Liu et al., 2014; Rufín et al., 2014) of egovernment services was one of the most significant influencing factors of e-government use or perception. Similarly, enourmous studies underline the crucial role of perceived trustworthiness (Hung et al., 2006; Horst et al., 2007; Lean et al., 2009; Alomari et al., 2010; Susanto \& Goodwin, 2010; Ozkan \& Kanat, 2011; Rufín et al., 2012; Aladwani, 2013; Hung et al., 2013; Mostafa \& El-Masry, 2013; Weerakkody et al., 2013) on the intention to use e-government services. Apart from these factors, perceived complexity (Lean et al., 2009), perceived image (Lean et al., 2009; Liu et al., 2014), and other service quality dimensions (Bwalya, 2009; Hamner \& Al-Qahtani, 2009; Al-Jaghoub et al., 2010; Susanto \& Goodwin, 2010; Ahmad et al., 2013; Alawneh et al., 2013; Al Hujran et al., 2013; Weerakkody et al., 2013; Liu et al., 2014) greatly contribute to the existing e-government literature. 


\section{Research Methodology}

\subsection{Ordered Response Models}

Ordered categorical variables are frequently used in many social science applications. In principle, these type of variables denote the rank order of a particular attribute whilst such rankings do not necessarily represent the actual magnitudes on a substantive scale (Powers \& Xie, 2000). When the outcomes are naturally ordered, the researcher should notice the fact that the dependent variable is considered as both discrete and ordinal. In other words, if the dependent variable has three categories, a linear regression would recognize the difference between category 3 and 2 identically to the difference between category 2 and 1 (Borooah, 2002).

The probability of an observed outcome such as $y=m$ for given values of $x$ 's designates to the region of the distribution where $y^{*}$ between $\tau_{m-1}$ and $\tau_{m}$ as

$\operatorname{Pr}(y=m \mid x)=\operatorname{Pr}\left(\tau_{m-1} \leq y^{*}<\tau_{m} \mid x\right)$

where $\tau$ 's are thresholds and $y^{*}$ is the latent variable. When $y^{*}$ is substituted with $x \beta+\varepsilon$, Equation (1) can be rewritten as

$$
\operatorname{Pr}(y=m \mid x)=F\left(\tau_{m}-x \beta\right)-F\left(\tau_{m-1}-x \beta\right)
$$

where $F$ denotes the cumulative function for $\varepsilon$. Further, the ordered models can be developed as a nonlinear probability model without the idea of latent variables. For $m=1, J-1$, the odds that an outcome is then or equal to $m$ versus greater than $m$ given $x$ are as follows:

$$
\Omega_{\leq m \mid>m}(x) \equiv \frac{\operatorname{Pr}(y \leq m \mid x)}{\operatorname{Pr}(y>m \mid x)}
$$

For instance, assuming the logs of the odds is equal to

$$
\ln \Omega_{\leq m \mid>m}(x)=\tau_{m}-x \beta
$$

the odds of $m \leq 2$ versus $m>2$ can be computed. For a simple three-category, the odds will be as the following (Long \& Freese, 2001):

$$
\begin{aligned}
& \ln \frac{\operatorname{Pr}(y \leq 1 \mid x)}{\operatorname{Pr}(y>1 \mid x)}=\tau_{1}-\beta_{1} x_{1} \\
& \ln \frac{\operatorname{Pr}(y \leq 2 \mid x)}{\operatorname{Pr}(y>2 \mid x)}=\tau_{2}-\beta_{1} x_{1}
\end{aligned}
$$

Generalized ordered logit model can simply be defined as

$$
P\left(Y_{i}>j\right)=g\left(X \beta_{j}\right)=\frac{\exp \left(\alpha_{j}+X_{i} \beta_{j}\right)}{1+\left[\exp \left(\alpha_{j}+X_{i} \beta_{j}\right]\right.}, j=1,2, \ldots, M-1
$$

where $M$ is the number of categories of the ordinal dependent variable. Moreover, the parallel lines model estimated by ordered logit model is a special case of the generalized ordered logit model that can be written as

$$
P\left(Y_{i}>j\right)=g(X \beta)=\frac{\exp \left(\alpha_{j}+X_{i} \beta_{j}\right)}{1+\left[\exp \left(\alpha_{j}+X_{i} \beta_{j}\right]\right.}, j=1,2, \ldots, M-1
$$

It can be easily noticed that the parallel lines model differs from the standard generalized logit model except for the Betas that are the same for all categories. For instance, when there are four categories, first category $(J=1)$ is contrasted with category 2, 3, and 4 (Williams, 2006). Whilst the generalized model is frequently preferred, most researchers disregard the parallel lines assumption that is often violated (Fu, 1998). In that context, to overcome the limitations of parallel lines restrictions, partial proportional odds model is introduced as a special case of generalized logit model, whereas some of the Beta coefficients can differ. For instance, Equation (9) illustrates a partial proportional odds model which enables the Betas for $X 3$ to differ (Williams, 2006):

$$
P\left(Y_{i}>j\right)=g\left(X \beta_{j}\right)=\frac{\exp \left(\alpha_{j}+X 1_{i} \beta 1+X 2_{i} \beta 2+X 3_{i} \beta 3_{j}\right)}{1+\left[\exp \left(\alpha_{j}+X 1_{i} \beta 1+X 2_{i} \beta 2+X 3_{i} \beta 3_{j}\right)\right]}, j=1,2, \ldots, M-1
$$

Heterogeneous choice model provides the researchers to examine determinants of the conditional variance. For an ordered variable $y$ with $M$ categories, the full heterogeneous choice model can be written as 


$$
P\left(y_{i}>m\right)=\operatorname{invlogit}\left\{\frac{\sum_{k} x_{i k} \beta_{k}-\kappa_{m}}{\exp \left(\sum_{j} z_{i j} \gamma_{j}\right)}\right\}=\operatorname{invlogit}\left(\frac{\sum_{k} x_{i k} \beta_{k}-\kappa_{m}}{\sigma_{i}}\right), m=1,2, \ldots, M-1
$$

where variance equation ${ }^{\sigma_{i}}$ can be defined as

$$
\sigma_{i}=\exp \left(\sum_{j} z_{i j} \gamma_{j}\right)
$$

For any given response, the full heterogeneous choice model in Equation (10) presents how the choice and variance equations are combined to put forward the probability (Williams, 2010).

Though regression parameters yield information about the sensitivity of a dependent variable regarding changes in several independent variables, in some circumstances, it may be more appropriate to measure these sensitivities in terms of percentages, where elasticities are also preferred. However, standard elasticity calculation is not considered as a valid measurement for indicator variables which were defined as dummies ( 1 for success and 0 for failure). For these types of variables a pseudo-elasticity measure given by

$$
E_{x_{k i}}^{P(i)}=\frac{\exp \left[\Delta\left(\beta_{i} x_{i}\right)\right] \sum_{\forall I} \exp \left(\beta_{k l} x_{k I}\right)}{\exp \left[\Delta\left(\beta_{i} x_{i}\right)\right] \sum_{\forall I} \exp \left(\beta_{k I} x_{k I}\right)+\sum_{\forall I \neq I_{n}} \exp \left(\beta_{k l} x_{k I}\right)}-1
$$

can be used, where $I_{n}$ denotes the set of alternate outcomes with ${ }^{x_{k}}$ in the function determining the outcome, and I denotes the set of all possible outcomes. These elasticities capture the potential effect that a change in a variable determining the likelihood of alternative outcome $i$ has on the probability this outcome will be selected, which are also called as direct elasticities (Washington et al., 2003).

\subsection{Study Design, Sample and Data Collection}

The present study utilized the data from 2011 Life Satisfaction Survey contucted by Turkish Statistical Institute among 2,052 Turkish citizens after excluding the non-users of e-government services and respondents who did not have any idea. The corresponding survey involved detailed questions about respondents' demographic characteristics and satisfaction levels regarding a number of government services. The dependent variable of this study for the fitted models investigates whether government services make life easier. This question was involved in the survey only in 2011 , so the data of this year were used in the model. The independent variable of this study had four ordinal categories, namely, 1 accounts for 'e-government services do not make life easier'; 2 accounts for 'e-government services somewhat make life easier'; 3 accounts for 'e-government services make life easier'; and finally 4 accounts for 'e-government services definitely make life easier'. Due to the ordinal and discrete nature of the dependent variable, four distinctive ordered responses models were fitted, separately, such as ordered logit model, generalized ordered logit model, partial constrained generalized ordered model, and heterogeneous choice model. For simplicity, only seven independent variables were involved in the final model including current residence, gender, age, household size, marital status, educational level, and occupational sector. The estimation results may also test the consistency of four models and provide the policy makers a benchmarking facility to decide on which model fits well.

\section{Estimation Results}

\subsection{Descriptive Statistics}

Table 1 indicates the descriptive statistics of variables used in the fitted modelds. As outlined in Table 1, a majority of the respondents $(55.5 \%)$ believe that e-government services make life easier in the sample year. More than half of the respondents (56.8\%) were men and very most of them (85.0\%) had currently urban lives. More than $70 \%$ of the respondents $(70.8 \%)$ were married and more than half of them (56.3\%) were secondary- or higher-educated. Nearly $45 \%$ of the respondents (44.74\%) were working at the private sector. Finally, the average age of the respondents was 37.61 and the average household size for the respondents was nearly four (3.75) people. 
Table 1. Descriptive Statistics of Variables

\begin{tabular}{|c|c|c|c|c|c|}
\hline Variable & Freq. & Percent & Variable & Freq. & Percent \\
\hline Current residence & & & Perception of e-government services & & \\
\hline Rural & 307 & 14.96 & Do not make life easier & 34 & 1.66 \\
\hline Urban ${ }^{a}$ & 1745 & 85.04 & Somewhat make life easier & 560 & 27.29 \\
\hline Gender & & & Make life easier & 1138 & 55.46 \\
\hline Female & 885 & 43.13 & Definitely make life easier ${ }^{a}$ & 320 & 15.59 \\
\hline Male $^{\mathrm{a}}$ & 1167 & 56.87 & Occupational sector & & \\
\hline Marital status & & & Public sector & 296 & 14.42 \\
\hline Married & 1452 & 70.76 & Private sector & 918 & 44.74 \\
\hline Single ${ }^{a}$ & 600 & 29.24 & Retired & 195 & 9.50 \\
\hline Education level & & & Unemployed ${ }^{a}$ & 643 & 31.34 \\
\hline Illiterate & 77 & 3.75 & Average age $=37.61(13.46)^{b}$ & & \\
\hline Literate/Primary education & 820 & 39.96 & Average household size $=3.75(1.66)^{b}$ & & \\
\hline Secondary education & 597 & 29.10 & & & \\
\hline Higher education ${ }^{\mathrm{a}}$ & 558 & 27.19 & & & \\
\hline
\end{tabular}

Notes: a reference category; ${ }^{\text {b }}$ standard deviation

\subsection{Estimation Results}

The econometric models were fitted by two similar user-written programs in Stata (Williams, 2006, 2010). Table 2 follows a similar design by Quddus et al. (2010) which presents the estimation results for four fitted ordered response models and provides a comparison of each models. The parallel lines assumption test proposed by Brant (1990) was carried out to determine whether the corresponding assumption was violated for the data used in the analysis, when a significant test statistic confirms the assumption violation. It was found that current residence; literate or primary education; public and private sector variables did not meet the assumption since their coefficients differed across different thresholds. These findings suggest that ordered logit model is a misspecified model and other three models were more convenient for interpretation. It can be noticed that variables which did not meet the parallel lines assumption were also used as factors affecting the error variance for heterogeneous choice model in Table 2. In addition, whilst the log-likehood values at convergence for four models were quiet similar, partial generalized logit model has the smallest AIC value which implies that this model fits better than other three models. As all of the independent variables used in the final fitted models except for age and household size were indicator variables, direct pseudo-elasticities were calculated in Table 3 to increase sensitivity of the results. The possible effects of the independent variables on Turkish citizens' perception regarding e-government services were interpreted using direct pseudo-elasticities.

As outlined in Table 3, for heterogeneous choice model, respondents who were living in urban areas were $19.8 \%$ more likely to think that e-government services make life somewhat easier and $36.9 \%$ less likely to think e-government services definitely make life easier than respondents living in rural areas. Respondents' educational level was found as a possible indicator for Turkish citizens' perception of e-government services. Accordingly, literate or primary-educated respondents $13.3 \%$ were less likely think that e-government services definitely make life easier than higher-educated counterparts. Respondents' occupational sector was another influencer of e-government perception. Respondents who work in public sector were $48.2 \%$ less likely to think that e-government services do not make life easier than unemployed respondents. Interestingly, respondents who work in private sector were $132.7 \%$ less likely to think that e-government services do not make life easier. Respondents who work in public and private sector were $25.2 \%$ and $72.0 \%$ less likely to think that e-government services had moderate contribution to human life, respectively. Respondents who work in public and private sector were $6.7 \%$ and $18.5 \%$ more likely to think that e-government services make life easier. Finally, respondents who work in public and private sector were $20.6 \%$ and $62.5 \%$ more likely to think that e-government services definitely make life easier, respectively.

For generalized ordered logit model, respondents who live in urban areas were $8.8 \%$ more likely to think that egovernment services make life easier. In contrast, respondents who live in urban areas were $51.2 \%$ less likely to think that e-government services definitely make life easier than respondents who live in rural areas. Household size was statistically significant for only generalized ordered logit model. Accordingly, household size increases the probability of respondents who think e-government services make life easier by $7.2 \%$, while household size decreases the probability of respondents who think e-government services definitely make life easier by $36.5 \%$. Educational level was another potential indicator of citizens' perception of e-government services. Literate or primary-educated respondents were 39.6\% more likely think e-government services do not make life easier. Interestingly, these respondents were also 5.3\% more likely to think that e-government services make life easier than higher-educated counterparts. Occupational sector was a statistically significant indicator for the perception of e-government services. Respondents working in private sector were 
43.2\% more llikely to think that e-government services do not make life easier than unemployed respondents. Respondents working in public sector were $33.0 \%$ less likely to think that e-government services had moderate contribution to human life. In contrast, respondents working in private sector were $99.8 \%$ less likely to think that egovernment services somewhat make life easier. Respondents working in public and private sector were $8.3 \%$ and $24.7 \%$ more likely to think that e-government services make life easier, respectively. Finally, respondents who work in public and private sector were $11.0 \%$ and $31.3 \%$ more likely to think that e-government services definitely make life easier.

For partial constrained generalized ordered logit model, respondents who were living in urban areas were $8.0 \%$ more likely to think that e-government services make life easier. Respondents who were living in rural areas were $49.4 \%$ less likely to think that e-government services definitely make life easier. Educational level was an indicator of egovernment service perception. Literate or primary educated respondents were $22.9 \%$ more likely to think that egovernment services do not make life easier. Literate or primary educated respondents were $4.9 \%$ more likely to think that e-government services make life easier. These respondents were $18.9 \%$ less likely to think that e-government services definitely make life easier. Occupational sector was the indicator of e-government service perception. Respondents who work in private sector was $35.3 \%$ more likely to think that e-government services do not make life easier. In contrast, respondents who work in public sector were $31.6 \%$ less likely to think that e-government services somewhat make life easier. Respondents who work in private sector were $97.7 \%$ less likely to think that e-government services somewhat make life easier. Respondents who work in public and private sector were $7.6 \%$ and $23.6 \%$ more likely to think that e-government services make life easier than unemployed respondents, respectively. Respondents who work in public and private sector were $12.1 \%$ and $33.0 \%$ more likely to think that e-government services definitely make life easier.

Table 2. Model Estimation Results for Ordered Logit, Heterogeneous Choice, Generalized Ordered Logit and Partial Constrained Generalized Ordered Logit Models

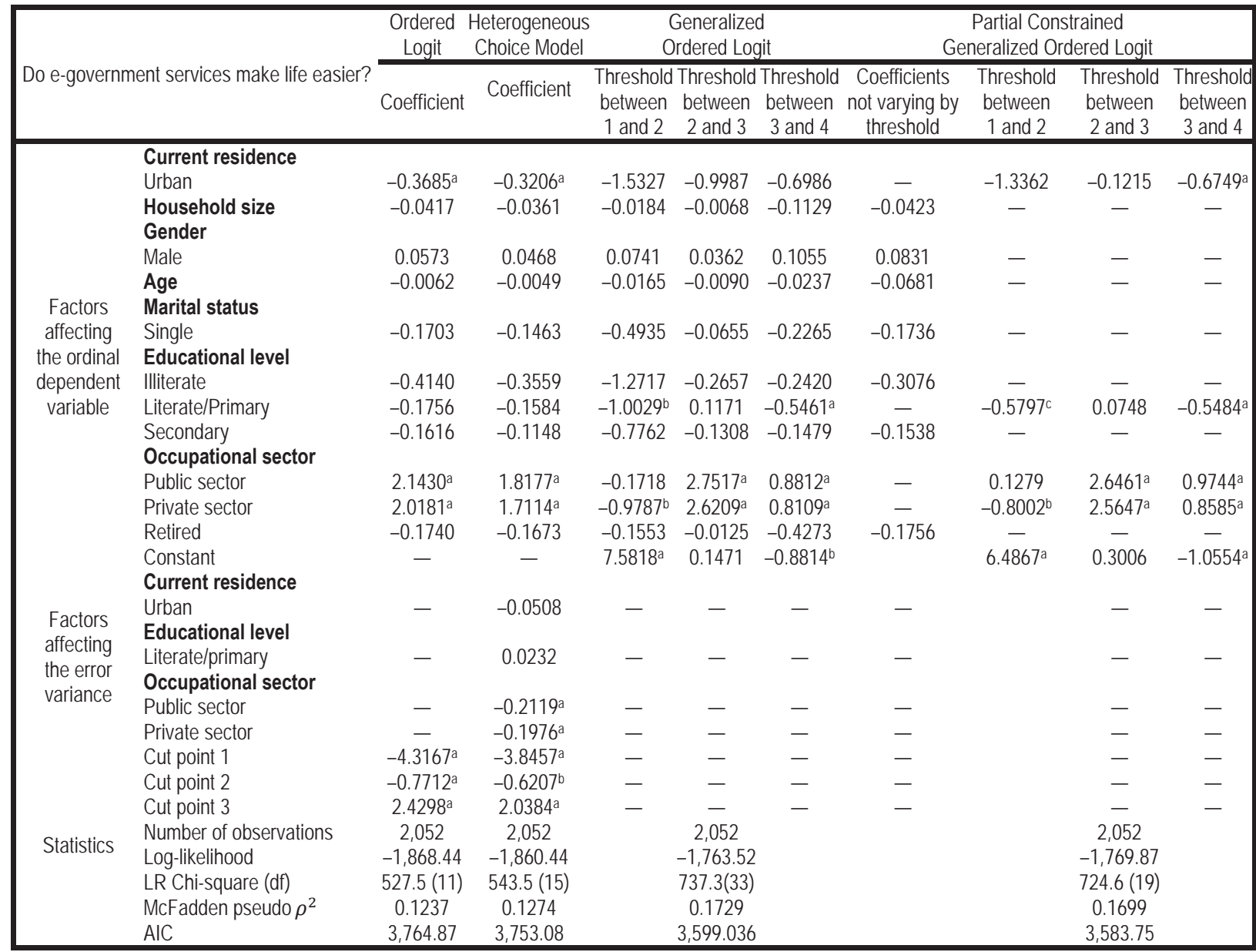

Notes: a significant at $99 \% ;{ }^{\text {b }}$ significant at $95 \% ;{ }^{\circ}$ significant at $90 \%$ 
Table 3. Average Direct Pseudo-elasticity of variables

\begin{tabular}{|c|c|c|c|c|}
\hline \multirow[b]{2}{*}{ Independent variables } & \multicolumn{4}{|c|}{ Pseudo-elasticities } \\
\hline & $\begin{array}{l}\text { Ordered Logit } \\
\text { Model }\end{array}$ & $\begin{array}{c}\text { Heterogeneous } \\
\text { Choice } \\
\text { Model }\end{array}$ & $\begin{array}{l}\text { Generalized Logit } \\
\text { Model }\end{array}$ & $\begin{array}{l}\text { Partial Generalized Logit } \\
\text { Model }\end{array}$ \\
\hline Current residence; urban [1] & $0.3105^{a}$ & & & \\
\hline Current residence; urban [2] & $0.2329 a$ & $0.1983^{b}$ & & \\
\hline Current residence; urban [3] & $-0.0431^{a}$ & & $0.0879 \mathrm{~b}$ & $0.0803^{b}$ \\
\hline Current residence; urban [4] & $-0.2789 a$ & $-0.3694^{a}$ & $-0.5118^{a}$ & $-0.4936^{a}$ \\
\hline Household size [3] & & & $0.0720^{c}$ & \\
\hline Household size [4] & & & $-0.3651^{b}$ & \\
\hline $\begin{array}{l}\text { Educational level; literate/primary } \\
\text { education [1] }\end{array}$ & & & $0.3956^{b}$ & $0.2285^{c}$ \\
\hline $\begin{array}{l}\text { Educational level; literate/primary } \\
\text { education [3] }\end{array}$ & & & $0.0532^{a}$ & $0.0493^{a}$ \\
\hline $\begin{array}{l}\text { Educational level; literate/primary } \\
\text { education [4] }\end{array}$ & & $-0.1330^{b}$ & & $-0.1885^{a}$ \\
\hline Occupational sector; public sector [1] & $-0.3062^{a}$ & $-0.4815^{a}$ & & \\
\hline Occupational sector; private sector [1] & $-0.8944^{a}$ & $-1.3274^{a}$ & $0.4322^{b}$ & $0.3531^{b}$ \\
\hline Occupational sector; public sector [2] & $-0.2297^{a}$ & $-0.2515^{a}$ & $-0.3303^{a}$ & $-0.3160^{a}$ \\
\hline Occupational sector; private sector [2] & $-0.6708^{a}$ & $-0.7203^{a}$ & $-0.9981^{a}$ & $-0.9766^{a}$ \\
\hline Occupational sector; public sector [3] & $0.0425^{a}$ & $0.0671^{a}$ & $0.0827^{a}$ & $0.0760^{a}$ \\
\hline Occupational sector; private sector [3] & $0.1242^{\mathrm{a}}$ & $0.1852^{\mathrm{a}}$ & $0.2465^{a}$ & $0.2356^{a}$ \\
\hline Occupational sector; public sector [4] & $0.2751^{\mathrm{a}}$ & $0.2059^{a}$ & $0.1095^{a}$ & $0.1209 a$ \\
\hline Occupational sector; private sector [4] & $0.8035^{a}$ & $0.6248^{a}$ & $0.3126^{a}$ & $0.3303^{a}$ \\
\hline
\end{tabular}

Notes: [1] E-government services do not make life easier;

[2] E-government services somewhat make life easier;

[3] E-government services make life easier;

[4] E-government services definitely make life easier

a significant at $99 \%$; b significant at $95 \%$; c significant at $90 \%$

\subsection{Model Specification}

Before estimating any models using the data, a multicollinearity test among the independent variables was carried out. Table 4 exhibits the variance inflation factor (VIF) values of the relevant independent variables included in the four fitted models. Practically, variables which have VIF values more than 10 are considered as they lead to multicollinearity problem and biased results. As shown in Table 4, none of the independent variables had VIF values more than 10 confirming the absence of multicollinearity in the data.

Table 4. Multicollinearity Test

\begin{tabular}{|lcc|}
\hline Independent variable & VIF & 1/VIF \\
\hline Current residence & & \\
Urban & 1.94 & 0.514 \\
Household size & 1.93 & 0.518 \\
Gender & & \\
Male & 1.82 & 0.548 \\
Age & 1.76 & 0.569 \\
Marital status & & \\
Single & 1.73 & 0.577 \\
Educational level & & \\
Illiterate & 1.66 & 0.602 \\
Literate/Primary education & 1.43 & 0.701 \\
Secondary education & 1.33 & 0.751 \\
Occupational sector & & \\
Public sector & 1.30 & 0.769 \\
Private sector & 1.16 & 0.860 \\
Retired & 1.07 & 0.934 \\
\hline Mean VIF & 1.56 & \\
\hline
\end{tabular}




\section{Discussion}

A very recent prior work (Aldawani, 2013) argues that lack of emphasis on actual e-government users is one the most important shortcomings of previous studies. In this respect, the present study used actual e-government users' data for the fitted models which may contribute to the existing e-government research. Recent studies (Verdegem \& Verleye, 2009; Osman et al., 2014) suggest that shortlist of satisfaction determinants for e-government services may employ to get a clear view on e-government perception. The main objective of the present study was to determine potential demographic attributes of e-government perception in a developing country where the citizens use the Internet intensively. For this purpose, the data were analyzed using four different ordered response models to provide a benchmarking. The results of all models were generally showed consensus, and although there was no important difference among all models, partial constrained generalized model was more parsimonious than other three models. Results reveal that current residence, educational level and occupational sector were the potential indicators of egovernment perception regarding whether e-government services make life easier. Specifically, household size was the additional indicator for heterogeneous choice model. Many earlier studies (Jaeger, 2003; Akman et al., 2005; Li et al., 2005; Hamner \& Al-Qahtani, 2009; Gauld et al., 2010; Aladwani, 2013; Naralan et al., 2013; Venkatesh et al., 2014) found that educational level was a significant indicator that was consistent with the results of the present study. Results of this study also shows consensus with other past work (Liu et al., 2014), in which current residence was a statistically significant indicator.

Past research suggests that achieving a significant level of flexibility and efficiency of instant interaction with government is much more challenging for developing countries. The success depends on tendency of the government in developing countries to decentralize responsibility and process and use electronic means (Basu, 2004). Similarly, developing countries may experience poor citizen utilization of their e-government initiatives and thus, the adoption of certain criteria may positively contribute in improving effective factors (Alshawi \& Alalwany, 2009). Results of this study revealed that respondents who live in urban areas were less satisfied citizens than rural counterparts. Results also indicated that household size decreased the probability of respondents who think e-government services definitely make life easier. Policy makers may consider improved e-government initiatives which substantially capture citizens' dissatisfaction. As e-government users living in urban territories possess higher percentages than other groups, their satisfaction should be increased for better e-government implementation. Another previous research (RodríguezDomínguez et al., 2011) underlines the linkage between e-government and a degree of economic development to enable citizens a certain standard of living and more efficient public services. Recent work (Gallego-Álvarez et al., 2010) confirms that authorized parties substantially attempt to promote the development of a dynamic and participatory egovernment. In this respect, increasing the satisfaction of urban groups may also contribute to the standard of living and economic development. Household size may be also considered for e-government improvement since satisfaction of larger families may facilitate to successful e-government implementation. According to estimation results, private sector was more satisfied than public sector. The dissatisfaction of public sector should be recognized because, no doubtly, more satisfied public workers would definitely contribute to the success of future e-government implementation.

This study had some limitations. The present study considers only demographic attributes and one selected year. As stated above, a great number of earlier studies (Hung et al., 2006; AlAwadhi \& Morris, 2009; Lean et al., 2009; Alomari et al., 2010; Verdegem \& Verdeye, 2009; Susanto \& Goodwin, 2010; Rufín et al., 2012; Venkatesh et al., 2012; Hung et al., 2013; Mostafa \& El-Masry, 2013; Liu et al., 2014; Rufín et al., 2014) specifically considered perceived ease of use as a significant indicator. Turkish Statistical Institute or other authorized institutions in Turkey should examine egovernment services in detail with more specific questions or surveys including future years. In addition, this study was probably the first attempt to compare several ordered response models in a study concerning e-government research. Future studies may also intend to make a comparison of more parsimonious models and they may also provide information about a benchmark between ordered and unordered models.

\section{References}

Ahmad, M.O., Markkula, J., \& Oivo, M. (2013). Factors affecting e-government adoption in Pakistan: a citizen's perspective. Tranforming Government: People, Process and Policy, 7(2), 225-239.

Akman, I., Yazici, A., Mishra, A., \& Arifoglu, A. (2005). E-Government: A global view and an empirical evaluation of some attributes of citizens. Government Information Quarterly, 22(2), 239-257.

AlAwadhi, S., \& Morris, A. (2009). Factors influencing the adoption of e-government services. Journal of Software. 4(6), 584-590.

Alawneh, A., Al-Refai, H., \& Batiha, K. (2013). Measuring user satisfaction from e-Government services. Lessons from Jordan. 
Government Information Quarterly, 30(3), 277-288.

Aldrich, D., Bertot, J.C. \& McClure, C.R. (2005). E-Government: initiatives, developments, and issues. Government Information Quarterly, 19(4), 349-355.

Al Hujran, O., Aloudat, A., Altarawneh, I. (2013). Factors influencing citizen adoption of e-government in developing countries: The case of Jordan. International Journal of Technology and Human Interaction, 9(2), 1-19.

Al-Jaghoub, S., Al-Yaseen, H., \& Al-Hourani, M. (2010). Evaluation of awareness and acceptability of using e-Government services in developing countries: the case of Jordan. The Electronic Journal of Information Systems Evaluation, 13(1), 1-8.

Alomari, M.K., Sandhu, K., \& Woods, P. (2010). Measuring social factors in e-government adoption in the Hashemite Kingdom of Jordan. International Journal of Digital Society, 1(2), 123-134.

Alshawi, S., \& Alalwany, H. (2009). E-government evaluation: Citizen's perspective in developing countries. Information Technology for Development, 15(3), 193-208.

Basu, S. (2004). E-government and developing countries: an overview. International Review of Law, Computers and Technology, 18(1), $109-132$.

Borooah, V.K. (2002). Logit and probit: Ordered and multinomial models, Thousand Oaks, California: SAGE Publications.

Brant, R. (1990). Assessing probability in the proportional odds model for ordinal logistic regression. Biometrics, 46(4), 1171-1178.

Bwalya, K.J. (2009). Factors affecting adoption of e-government in Zambia. 38(4), The Electronic Journal of Information Systems in Developing Countries, 38(4), 1-13.

Choudrie, J., \& Dwivedi, Y.K. (2005). A survey of citizens' awareness and adoption of e-government inititatives, the 'government gateway': a United Kingdom perspective. eGovernment Workshop '05(eGOV05), Brunei University, UK.

DeBenedictis, A., Howell, W., Figueroa, R., \& Boggs, R. (2002). E-government defined: An overview of the next big information technology challenge. Issues in Information Systems, 3(1), 130-136.

$\mathrm{Fu}, \mathrm{V}$. (1998). Estimating generalized ordered logit models. Stata Technical Bulletin 44 , 27-30. Stata technical bulletin reprints, Vol. 8, College Station, Tex.: Stata Press, 160-164.

Gallego-Álvarez, Rodríguez-Domínguez, \& García-Sánchez, I.M. (2010). Are determining factors of municipal E-government common to a worlwide municipal view? An intra-country comparison. Government Information Quarterly, 27(4), 423-430.

Gauld, R., Goldfinch, S., \& Horsburgh, S. (2010). Do they want it? Do they use it? The 'Demand-Side' of e-Government in Australia and New Zealand. Government Information Quarterly, 27(2), 177-186.

Gil-Garcia, J.R., \& Martinez-Moyano, I.J. (2007). Understanding the evolution of e-government: The influence of systems of rules on public sector dynamics. Government Information Quarterly, 24(2), 266-290.

Grant, G., \& Chau, D. (2005). Developing a generic framework for e-government. Journal of Global Information Management, 13(3), 112.

Hamner, M., \& Al-Qahtani, F. (2009). Enhancing the case for Electronic Government in developing nations: A people-centric study focused in Saudi Arabia. Government Information Quarterly, 26(1), 137-143.

Ho, A.T.K. (2002). Reinventing local governments and the e-government initiative. Public Administration Review, 62(3), 434-444.

Horst, M., Kuttschreuter, Gutteling, J.M. (2007). Perceived usefulness, personal experiences, risk perception and trust as determinants of adoption of e-government services in the Netherlands, Computers in Human Behavior, 23(4), 1838-1852.

Hung, S.Y., Chang, C.M., \& Yu, T.J. (2006). Determinants of user acceptance of the e-Government services: The case of tax filing and payment system. Government Information Quarterly, 23(1), 97-122.

Hung, S.Y., Chang, C.M., \& Kuo, S.R. (2013). User acceptance of mobile e-government services: An empirical study. Government Information Quarterly, 30(1), 33-44.

Internet World Stats (2013). Top ten countries with the highest number of the Internet users. Available at <http://www.internetworldstats. com/stats4.htm\#europe> (accessed November 5, 2014).

Jaeger, P.T. (2003). The endless wire: E-government as global phenomenon. Government Information Quarterly,20(4), 323-331.

Kaya Bensghir, T., \& Yildiz, M. (2002). Perceptions of e-government in Turkey. Turkish Public Administration Annual, 27-28, 41-57.

Layne, K., \& Lee, J. (2001). Developing a fully functional E-government: A four stage model. Government Information Quarterly, 18(2), $122-136$.

Lean, O.K., Zailani, S., Ramayah, T., \& Fernando, Y. (2009). Factors influencing intention to use e-government services among citizens in Malaysia. International Journal of Information Management, 29(6), 458-475.

Li, H., Detenber, B.H., Lee, W.P., \& Chia, S. E-Government in Singapore. Journal of E-Government, 1(3), 29-54.

Liu, Y., Li, H., Kostakos, V., Goncalves, J., Hosio, S., \& Hu, F. (2014). An empirical investigation of mobile government adoption in rural China: A case study in Zhejiang province. Government Information Quarterly, 31(3), 432-442.

Long, J.S., \& Freese, J. (2001). Regression models for categorical dependent variables using Stata. College Station, Texas: Stata Press.

Mostafa, M.M., \& El-Masry, A.A. (2013). Citizens as consumers: Profiling e-government services' users in Egypt via data mining techniques. International Journal of Information Management, 33(4), 627-641.

Nam, T. (2014). Determining the type of e-government use. Government Information Quarterly, 31(2), 211-220.

Naralan, A., Çelik, A.K., \& Bakan, S. (2013). E-government adoption among citizens: The case study of health care workers in a rural Turkish hospital. Research Journal of Economics, Business and ICT, 8(2), 44-54.

Powers, D.A., \& Xie, Y. (2000), Statistical methods for categorical data analysis. San Diego, California: Academic Press.

Osman, I.H., Anouze, A.L., Irani, Z., Al-Ayoubi, B., Lee, H., Balcı, A., Medeni, T.D., \& Weerakkody, V. (2014). COBRA framework to evaluate e-government services: A citizen-centric perspective. Government Information Quarterly, 31(2), 243-256. 
Ozkan, S., \& Kanat, I.E. (2011). E-Government adoption model based on theory of planned behavior: Empirical validation. Government Information Quarterly, 28(4), 503-513.

Quddus, M.A., Wang, C., \& Ison, S.G. (2010). Road traffic congestion and crash severity: Econometric analysis using ordered response models. Journal of Transportation Engineering, 136(5), 424-435.

Rey, D., \& Ozymy, J. (2011). Predicting e-government use and public support for computer access and training: Employing two distinct theoretical approaches. Journal of Information Technology and Politics, 8(1), 68-82.

Rodríguez-Domínguez, L., García Sánchez, I.M., \& Gallego Álvarez, I. (2011). Determining factors of e-government development: A worldwide national approach. International Public Management Journal, 14(2), 218-248.

Rufín, R., Bélanger, F., Medina Molina, C., Carter, L., \& Sánchez Figueroa, J.C. (2014). A cross-cultural comparison of electronic government adoption in Spain and the USA. International Journal of Electronic Government Research, 10(2), 43-59.

Rufín, R., Medina, \& Sánchez Figueroa, J.C. (2012). Moderating factors in adopting local e-government in Spain. Local Government Studies, 38(3), 367-385.

Susanto, T.D., \& Goodwin, R. (2010). Factors influencing citizen adoption of SMS-Based e-Government Services. Electronic Journal of e-Government, 8(1), 55-71.

The National E-government Official Website of Turkey (2014), The number of registered users, services and organizations. Available at $<$ https://www.turkiye.gov.tr> (accessed October 30, 2014).

Tseng, P.T.Y., Yen, D.C., Hung, Y.C., \& Wang, N.C.F. (2008). To explore managerial issues and their implications on e-Government deployment in the public sector: Lessons from Taiwan's Bureau of Foreign Trade. Government Information Quarterly, 25(4), 734756.

TURKSAT (2009) E-government gateway. Available at <http://www.turksat.com.tr/en/what-is-e-state-office> (accessed November 5, 2014).

Venkatesh, V., Chan, F.K.Y., \& Thong, J.Y.L. (2012). Designing e-government services: Key service attributes and citizens' preference structures. Journal of Operations Management, 30(1-2), 116-133.

Venkatesh, V., Sykes, T.A., \&Venkatraman, S. (2014). Understanding e-Government portal use in rural India: role of demographic and personality characteristics. Information Systems Journal, 24(3), 249-269.

Verdegem, P., \& Verleye, G. (2009). User-centered E-Government in practice: A comprehensive model for measuring user satisfaction. Government Information Quarterly, 26(3), 487-497.

Yildiz, M. (2007). E-government research: Reviewing the literature, limitations, and ways forward. Government Information Quarterly, 24(3), 646-665.

Washington, S.P., Karlaftis, M.G., \& Mannering, F.L. (2003). Statistical and econometric methods for transportation data analysis. New York: Chapman \& Hall/CRC.

Weerakkody, V., El-Haddadeh, R., Al-Sobhi, F., Shareef, M.A., \& Dwivedi, Y.K. (2013). Examining the influence of intermediaries in facilitating e-government adoption: An empirical investigation. Government Information Quarterly, 716-725.

Williams, R. (2006). Generalized ordered logit/partial proportional odds models for ordinal dependent variables. The Stata Journal, 6(1), 58-82.

Williams, R. (2010). Fitting heterogeneous choice models with oglm. The Stata Journal, 10(4), 540-567. 